Article

\title{
A Novel Early Warning System (EWS) for Water Quality, Integrating a High-Frequency Monitoring Database with Efficient Data Quality Control Technology at a Large and Deep Lake (Lake Qiandao), China
}

\author{
Liancong Luo ${ }^{1, *} * \mathbb{D}$, Jia Lan ${ }^{2}$, Yucheng Wang ${ }^{2}$, Huiyun $\mathrm{Li}^{3, *}, \mathrm{Zhixu} \mathrm{Wu}^{2}$, Chrisopher McBridge ${ }^{4}$, Hong Zhou ${ }^{5}$,
} Fenglong Liu ${ }^{6}$, Rufeng Zhang ${ }^{1}$, Falu Gong ${ }^{1}$, Jialong Li $^{1}$, Lan Chen ${ }^{1}$ and Guizhu Wu ${ }^{1}$

check for updates

Citation: Luo, L.; Lan, J.; Wang, Y.; Li, H.; Wu, Z.; McBridge, C.; Zhou, H.; Liu, F.; Zhang, R.; Gong, F.; et al. A Novel Early Warning System (EWS) for Water Quality, Integrating a High-Frequency Monitoring Database with Efficient Data Quality Control Technology at a Large and Deep Lake (Lake Qiandao), China. Water 2022, 14, 602. https://doi.org/ $10.3390 / w 14040602$

Academic Editors: Fei Zhang, Ngai Weng Chan, Xinguo Li and Xiaoping Wang

Received: 31 December 2021 Accepted: 13 February 2022 Published: 16 February 2022

Publisher's Note: MDPI stays neutral with regard to jurisdictional claims in published maps and institutional affiliations.

Copyright: (C) 2022 by the authors. Licensee MDPI, Basel, Switzerland. This article is an open access article distributed under the terms and conditions of the Creative Commons Attribution (CC BY) license (https:// creativecommons.org/licenses/by/ $4.0 /)$.
1 Institute for Ecological Research and Pollution Control of Plateau Lakes, School of Ecology and Environmental Science, Yunnan University, Kunming 650504, China; hangrufeng1997@126.com (R.Z.); gongfl2022@163.com (F.G.); jlli@mail.yun.edu.cn (J.L.); 15111718997@163.com (L.C.); wuguizhu0223@163.com (G.W.)

2 Chunan Branch, Hangzhou Municipal Ecology and Environment Bureau, Chunan 311700, China; lanika0916@163.com (J.L.); iceman0011@163.com (Y.W.); caepb@126.com (Z.W.)

3 Nanjing Institute of Geography and Limnology, Chinese Academy of Sciences, Nanjing 210008, China

4 Environmental Research Institute, The University of Waikato, Hamilton 3240, New Zealand; christopher.mcbride@waikato.ac.nz

5 Waikato Institute of Technology, Hamilton 3204, New Zealand; hong.zhou@wintec.ac.nz

6 Financial Department, Hunan University of Humanities, Science and Technology, Loudi 417000, China; 13907384452@139.com

* Correspondence: billluo@ynu.edu.cn (L.L.); hyli@niglas.ac.cn (H.L.); Tel.: +86-(0)-181-1290-7530 (L.L.); +86-(0)-159-0515-7570 (H.L.)

Abstract: To assess water quality (WQ) online for assuring the safety of drinking water, a novel early warning system integrating a high-frequency monitoring system (HFMS) and data quality control (QC) was developed at Lake Qiandao. The HFMS was designed for monitoring water quality, nutrient inputs by main tributaries, water currents and meteorology at different sites at Lake Qiandao. The EWS focused on data availability, a QC method, a statistical analysis method and data applications instead of technological aspects for sondes, wireless data transfer and interface software development. QC was implemented before use to delete the abnormal values of outliers, to detect change points, to analyse the change trend, to interpolate discrete missing measurements, and find continuous missing or wrong observations caused by technical problems with the sonde. For demonstrating advantages and data availability, surface and profiling measurements at two sites were plotted. The plots show obvious seasonal and diel variations, demonstrating the success of integration of the system with advanced automated technology and good QC. This successfully developed system is now not only giving early warning signals, but also providing critical WQ information for the security of drinking water diverted to Hangzhou city through a tunnel of $110 \mathrm{~km}$ length. The automatic monitoring data with QC is also being used to produce initial conditions for WQ prediction based on a three dimensional hydrodynamic-ecosystem model.

Keywords: early warning system; high-frequency monitoring; data quality control; water quality; Lake Qiandao

\section{Introduction}

Lake eutrophication is a long-term global problem caused by excess nutrient inputs [1], and exacerbated by long water residence times that delay WQ responses to management actions. It is a common problem in the lakes located at the middle and lower catchment of the Yangtze River even in the "good WQ" lakes classified by the Ministry of Ecology 
and Environment of the People's Republic of China (e.g., Lake Qiandao). Impairments associated with eutrophication include poor water clarity, harmful algal blooms (HABs) [2-4], and the loss of biodiversity, which affect drinking water supplies and the recreational use of lakes. Some impairments are highly dynamic (e.g., HABs, loss of dissolved oxygen, etc.), which has resulted in the rapid proliferation of EWS for monitoring key variables that can cause rapid changes in the water quality of coastal water [5] and freshwater systems [6-10].

An EWS is an integrated system consisting of in situ autonomous sensors for continuous rapid monitoring. The measured data are analysed and interpreted for the purpose of forecasting changes in water quality by the system. It provides a fast and accurate way to distinguish abnormal/abrupt variations in WQ due to biochemical and physical interactions over short time scales. EWS requires the fast detection of abnormalities in WQ parameters, which calls for high-frequency real-time monitoring technologies, wireless communication and appropriate data storage and analysis. A new generation of online monitoring tools based on sensor sonde technology and satellite-based remote sensoring (RS) has emerged in recent years [11-16]. However, the effective implementation of these tools has not been fully realised due to their limitations relating to meeting practical utility needs, high costs, unsatisfied reliability, hardware maintenance demands, and cumbersome data management and analysis approaches, with respect to practical operations.

Conventional sample collection and laboratory-based methods are too slow to achieve operational response and temporal-spatial continuity. There is a clear and increasing need to rapidly detect $W Q$ parameters to ensure an appropriate and timely response to instances of accidental or deliberate contamination [13]. For the past two decades, Wireless Sensor Networks (WSNs) technology has been applied increasingly to environmental monitoring for providing high-frequency scientific data. These high-tech smart devices have offered a vital approach to environmental monitoring and have monitored some lesser-studied fundamental processes, due to their inaccessibility [12]. Generally, the sensor nodes acquire data autonomously, process them locally, and transfer the information to a base station with an internet connection [17].

WSN technology integrated with floating buoys has been widely used to acquire high-frequency WQ data for lakes in the world. Due to severe environmental problems, the Chinese great lakes, which were or are currently supplying drinking water, have been the focus of many efforts to build dense buoy monitoring networks. For example, on Lake Taihu (Jiangsu Province, surface area $2338 \mathrm{~km}^{2}$, mean water depth $1.9 \mathrm{~m}$ ), 18 WSN buoy stations are operated by the Chinese Academy of Science, 21 stations by the Jiangsu Environmental Monitoring Station [18], and one each by the Suzhou Meteorological Bureau and Nanjing Normal University. At Lake Dianchi (Yunnan Province, surface area $300 \mathrm{~km}^{2}$ ), there are 30 monitoring buoy stations (MBSs) [19]. Lake Taihu and Lake Dianchi are both key lakes which have been invested in tremendously by the Chinese central government for ecological restoration over the past two decades. At Lake Qiandao, which is a drinking water supply reservoir with an area of $580 \mathrm{~km}^{2}$ [20], there are four buoy profilers with a meteorological station, $10 \mathrm{MBS}$ for surface WQ detection with a meteorological station, 13 MBSs for inflow river WQ detection, and four for both surface WQ detection and current measurements by an Acoustic Doppler Current Profiler (ADCP).

Key issues that need to be addressed for a EWS in order to assure the accuracy and precision of measurements, are data quality control (QC) and quality assurance (QA). QC and QA are fundamental for decision making based on reliable data analysis. For a specific water quality parameter, QC generally involves a number of internal consistency tests, a threshold test, a step change point and trend detections for finding potential outliers at a particular station [21]. Measured data at a given site may also be compared with measurements from surrounding sites for an accuracy assessment. An effective QC and QA system is critical to the success of any environmental project, which has been successfully applied to the fields of climatology, oceanography and other geosciences. However, there has been limited application to developing an EWS with real-time highfrequency monitoring. Therefore, the aims of this study were to introduce a comprehensive 
EWS. developed for Lake Qiandao, and the corresponding QC method for real-time highfrequency monitoring data.

\section{Methodology}

\subsection{Study Area}

Built in 1959, Lake Qiandao is located at Chun'an County, which is at the west of Zhejiang Province, China $\left(29^{\circ} 22^{\prime}-9^{\circ} 50^{\prime} \mathrm{N}, 118^{\circ} 34^{\prime}-119^{\circ} 15^{\prime} \mathrm{E}\right.$, Figure 1) [22]. It is one of the largest reservoirs in China with a surface water area of $573 \mathrm{~km}^{2}$ and a water capacity of $178.4 \times 10^{8} \mathrm{~m}^{3}$, when the water level is $108 \mathrm{~m}$ [23]. The mean water depth is $34 \mathrm{~m}$ and the maximum depth is $100 \mathrm{~m}$. It is used to supply drinking water for the 450,000 people in Chun'an County. Now, it is also providing drinking water for five million people in Hangzhou City, through a tunnel with a length of $\sim 110 \mathrm{~km}$. There are 34 inflow tributaries around the lake. The largest one (Xinan River, Figure 1) is from the northwest, carrying $51.4 \%$ of the total inflow to the lake from all sources, not including rainfall and ground water. It carries $34.3 \%$ of the total phosphorus (TP) loading and $63.7 \%$ of the total nitrogen (TN) loading [19]. The multi-year average inflow and outflow are $103.44 \times 10^{8} \mathrm{~m}^{3}$ and $97.45 \times 10^{8} \mathrm{~m}^{3}$, respectively [23], with a residence time of $\sim 668$ days.

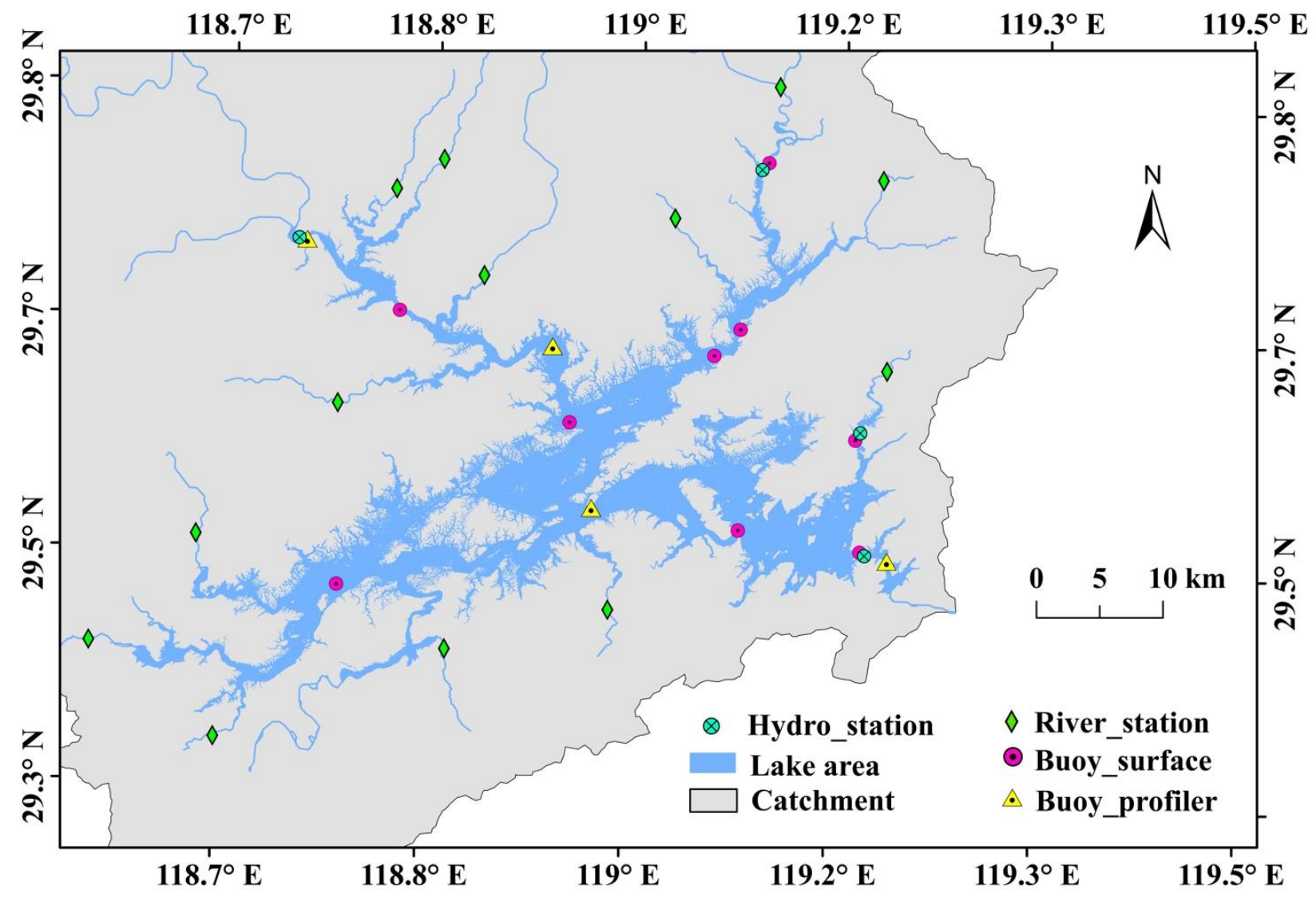

Figure 1. Monitoring sites at Lake Qiandao and its location within China.

\subsection{Monitoring Stations}

The HFMS at Lake Qiandao includes thirteen river stations; fourteen buoy stationsincluding ten buoys measuring the surface WQ (Buoy_surface, model EMM700, YSI Incorporated, Yellow Springs, USA); four 'profiler' buoys (Buoy_profiler, model EMM2500, Yellow Springs, USA); four hydrological stations (Hydro_station) - these were deployed at the three main tributaries and the only river outflow and measure water current speed; and four flux stations (Flux_station, model Tenghai HZF3, Tenghai Science \& Technology Ltd., Hangzhou, China), located alongside the hydrological stations, measuring WQ parameters. There are also thirteen river stations (River_station, model EMM700, YSI 
Incorporated, Yellow Springs, USA) measuring WQ, deployed at the main inflow tributaries. Meteorological sensors (Met_station) are deployed at the top of each buoy station, except for one site (Figure 1). The Buoy_profilers were deployed at sites 1-4. The profiling information at site 3 is representative of the lake because it is at the centroid, while site 4 is the deepest monitoring point, which is located at the biggest outflow channel. Sites 5 and 6 with Buoy_surface are near the middle, capturing surface WQ variation.

\subsection{Sensor Information and Alert Range}

Table 1 shows all the sensor metadata. The alert range for a specific sensor, in the seventh column of Table 1, was decided by analysing historical data manually, or by using the sonde measurements. The alert thresholds are equal to the corresponding reasonable "minimum-maximum-range" (MMR) of each sonde. When the measured value is out of the alert range, an alert report will be recorded and the EWS can find the report by searching alert report once an hour. Once alert information for a specific sonde is found, a message will be sent to the EWS manager's cellphone. The integrated sonders with a metal protective cage move up and down through the water column at a constant speed The average return times for sonders moving at site 1 , site 2 , site 3 and site 4 , are 55 min through a water column of $65 \mathrm{~m}, 45 \mathrm{~min}$ (water column $40 \mathrm{~m}$ ), $50 \mathrm{~min}$ (water column $46 \mathrm{~m}$ ), and $30 \mathrm{~min}$ (water column $16 \mathrm{~m}$ ), respectively. The measurement values are recorded every minute at all the four sites. All the buoy systems are solar-powered and the data are transferred to a computer server at the Chunan Branch of Hangzhou Ecology and Environment Bureau by $4 \mathrm{G}$ wireless telemetry. The whole monitoring system is being maintained by Hangzhou Tenghai Science and Technology Limited, with the sondes cleaned to wipe bio-fouling once a month and calibrated once every three months for data assurance. The power supply system with a solar panel and wireless data transfer are also regularly checked and maintained by this company.

Table 1. Sensor metadata for all monitoring buoys at Lake Qiandao.

\begin{tabular}{|c|c|c|c|c|c|c|c|}
\hline Buoy Type & $\begin{array}{l}\text { Number } \\
\text { of Buoys }\end{array}$ & $\begin{array}{l}\text { Measured } \\
\text { Parameter }\end{array}$ & Unit & $\begin{array}{l}\text { Sensor } \\
\text { Model }\end{array}$ & $\begin{array}{c}\text { Measurement } \\
\text { Range }\end{array}$ & Alert Range & $\begin{array}{l}\text { Monitoring } \\
\text { Frequency }\end{array}$ \\
\hline \multirow{6}{*}{$\begin{array}{l}\text { Buoy_- } \\
\text { surface }\end{array}$} & \multirow{5}{*}{10} & WT & ${ }^{\circ} \mathrm{C}$ & & $-5-+50$ & $9-35$ & \multirow{10}{*}{$30 \mathrm{~min}$} \\
\hline & & $\mathrm{PH}$ & & & $0-14$ & $6-9$ & \\
\hline & & ORP & $\mathrm{mV}$ & & $-999-+999$ & $-30-+500$ & \\
\hline & & COND & $\mathrm{mS} \mathrm{cm}^{-1}$ & & 0-200 & $80-170$ & \\
\hline & & DO_con & $\mathrm{mg} \mathrm{L}^{-1}$ & YSI & $0-50$ & $4-13$ & \\
\hline & \multirow{5}{*}{4} & DO_sat & $\%$ & $\mathrm{EXO} 2$ & $0-500$ & $39-170$ & \\
\hline \multirow{4}{*}{$\begin{array}{c}\text { Buoy_- } \\
\text { profiler }\end{array}$} & & TURB & NTU & & $0-4000$ & $0-43$ & \\
\hline & & CHLA & $\mu g \mathrm{~L}^{-1}$ & & $0-400$ & $0-25$ & \\
\hline & & PC & $\mu \mathrm{g} \mathrm{L}^{-1}$ & & $0-100$ & $0-7$ & \\
\hline & & FDOM & QSE & & $0-300$ & $0-7$ & \\
\hline \multirow{4}{*}{$\begin{array}{c}\text { River_ } \\
\text { station } \\
\text { (EMM700) }\end{array}$} & \multirow{4}{*}{13} & WT & ${ }^{\circ} \mathrm{C}$ & & $-5-+50$ & & \multirow{4}{*}{$2 \mathrm{~h}$} \\
\hline & & COND & $\mu S \mathrm{~cm}^{-1}$ & YSI & $0-200$ & & \\
\hline & & TURB & NTU & EXO2 & $0-4000$ & & \\
\hline & & FDOM & QSE & & $0-300$ & & \\
\hline \multirow{6}{*}{$\begin{array}{l}\text { Met_- } \\
\text { station }\end{array}$} & \multirow{6}{*}{13} & $\mathrm{RH}$ & $\%$ & & $0-100$ & $35-90$ & \multirow{6}{*}{$30 \mathrm{~min}$} \\
\hline & & $\mathrm{BP}$ & hpa & & $600-1100$ & 970-1030 & \\
\hline & & Wind_spd & $\mathrm{m} \mathrm{s}^{-1}$ & VAISALA & $0-60$ & $0-13$ & \\
\hline & & Wind_dir & ${ }^{\circ} \mathrm{C}$ & WXT520 & $0-360$ & $0-360$ & \\
\hline & & TEMP & ${ }^{\circ} \mathrm{C}$ & & $-52-+60$ & $1-33$ & \\
\hline & & RAIN & $\mathrm{mm}$ & & $0-200 \mathrm{~mm} \mathrm{~h}^{-1}$ & $0-162 \mathrm{~mm}$ day $^{-1}$ & \\
\hline \multirow{5}{*}{$\begin{array}{l}\text { Flux_- } \\
\text { station }\end{array}$} & \multirow{5}{*}{4} & $\mathrm{TN}$ & $\mathrm{mg} \mathrm{L}^{-1}$ & & & $0.4-1.5$ & \multirow{5}{*}{$1 \mathrm{~h}$} \\
\hline & & $\mathrm{TP}$ & $\mathrm{mg} \mathrm{L}^{-1}$ & & & $0-0.03$ & \\
\hline & & COD & $\mathrm{mg} \mathrm{L}^{-1}$ & Irius & $0-500$ & $4-11$ & \\
\hline & & $\mathrm{NO}_{3}-\mathrm{N}$ & $\mathrm{mg} \mathrm{L}^{-1}$ & & $0-100$ & $0-0.08$ & \\
\hline & & TOC & $\mathrm{mg} \mathrm{L}^{-1}$ & & $0-500$ & & \\
\hline
\end{tabular}


Table 1. Cont.

\begin{tabular}{|c|c|c|c|c|c|c|c|}
\hline Buoy Type & $\begin{array}{l}\text { Number } \\
\text { of Buoys }\end{array}$ & $\begin{array}{l}\text { Measured } \\
\text { Parameter }\end{array}$ & Unit & $\begin{array}{l}\text { Sensor } \\
\text { Model }\end{array}$ & $\begin{array}{c}\text { Measurement } \\
\text { Range }\end{array}$ & Alert Range & $\begin{array}{l}\text { Monitoring } \\
\text { Frequency }\end{array}$ \\
\hline $\begin{array}{l}\text { Hydro_ } \\
\text { Station }\end{array}$ & 4 & $\begin{array}{l}\text { Current } \\
\text { Speed }\end{array}$ & $\mathrm{m} \mathrm{s}^{-1}$ & $\begin{array}{c}\text { ADCP } \\
\text { TRDI } \\
\text { WHR600k }\end{array}$ & $0-5$ & $0-1$ & $30 \mathrm{~min}$ \\
\hline
\end{tabular}

Abbreviations: water temperature (WT), oxidation reduction potential (ORP), electrical conductivity (COND), dissolved oxygen concentration (DO_con), dissolved oxygen saturation (DO_sat), turbidity (TURB), chlorophyll $a$ (CHLA), phycocyanin (a pigment specific to cyanobacteria, PC), fluorescent dissolved organic matter (FDOM), total nitrogen (TN), total phosphorus (TP), chemical oxygen demand (COD), nitrate $\left(\mathrm{NO}_{3}{ }^{-} \mathrm{N}\right)$, total organic carbon (TOC), relative humidity (RH), air pressure (BP), wind speed (Wind_spd), wind direction (Wind_dir) and air temperature (TEMP).

\subsection{Data Quality Control}

The monitoring stations produce large volumes of data, requiring specialised tools to facilitate quality control and to ensure that data are fit-for-purpose. We developed bespoke software in Fortran, employing two principle methods of quality control. Firstly, an MMR was adopted whereby the minimum and maximum values of the raw data measured by each sensor were specified, by assessing the range of previous observations and defining a 'reasonable range' (larger than or equal to the alert range at Table 1) for each variable based on a large volume of historical measurements from the lake area and inflows/outflows. The lowest value from both historical observations was adopted as the minimum value for MMR, with the maximum value defined with a similar method. Table 2 shows all the maximum (Max)/minimum (Min)/average (Avg) values for WQ measurements including $\mathrm{WT}, \mathrm{pH}, \mathrm{DO}$, permanganate index (PI), chemical oxygen demand (COD), five-day biochemical oxygen demand $\left(\mathrm{BOD}_{5}\right)$, ammonia $\left(\mathrm{NH}_{4}-\mathrm{N}\right), \mathrm{TP}, \mathrm{TN}, \mathrm{CHLA}$ and Secchi depth (SD). Unfortunately, only WT, pH and DO were observed by the monitoring buoys. Subsequently, data outside of the specified range for each variable were quarantined with a unique flag number (e.g., '8888') and will be further investigated.

Table 2. Statistical value of measured water quality parameters at the four sites of Lake Qiandao from April 2001 to May 2021.

\begin{tabular}{|c|c|c|c|c|c|c|c|c|c|c|c|c|c|}
\hline Site & $\begin{array}{l}\text { Number of } \\
\text { Samples }\end{array}$ & $\begin{array}{l}\text { Statistical } \\
\text { Value }\end{array}$ & $\begin{array}{l}\text { WT } \\
\left({ }^{\circ} \mathrm{C}\right)\end{array}$ & $\mathrm{pH}$ & $\begin{array}{c}\text { DO } \\
\left(\mathrm{mg} \mathrm{L}^{-1}\right)\end{array}$ & $\begin{array}{c}\text { PI } \\
\left(\mathrm{mg} \mathrm{L}^{-1}\right)\end{array}$ & $\begin{array}{c}\text { COD } \\
\left(\mathrm{mg} \mathrm{L}^{-1}\right)\end{array}$ & $\begin{array}{c}\text { BOD }_{5} \\
\left(\mathrm{mg} \mathrm{L}^{-1}\right)\end{array}$ & $\begin{array}{l}\mathrm{NH}_{4}-\mathrm{N} \\
\left(\mathrm{mg} \mathrm{L}^{-1}\right)\end{array}$ & $\begin{array}{c}\text { TP } \\
\left(\mathrm{mg} \mathrm{L}^{-1}\right)\end{array}$ & $\begin{array}{c}\text { TN } \\
\left(\mathrm{mg} \mathrm{L}^{-1}\right)\end{array}$ & $\begin{array}{l}\text { CHLA } \\
\left(\mu \mathrm{g} \mathrm{L}^{-1}\right)\end{array}$ & $\begin{array}{l}\text { SD } \\
(\mathrm{m})\end{array}$ \\
\hline \multirow{3}{*}{ Site 1} & \multirow{3}{*}{195} & Max & 32.8 & 9.1 & 14.3 & 3.53 & 17.0 & 3.50 & 0.51 & 0.173 & 2.47 & 72 & 6.0 \\
\hline & & Min & 9.0 & 6.4 & 4.9 & 1.23 & 5.0 & 0.34 & 0.01 & 0.002 & 0.59 & 0.6 & 0.1 \\
\hline & & Avg & 20.5 & 7.7 & 8.7 & 1.96 & 7.0 & 1.05 & 0.08 & 0.029 & 1.24 & 9.5 & 2.39 \\
\hline \multirow{3}{*}{ Site 2} & \multirow{3}{*}{184} & Max & 34.3 & 8.8 & 14.9 & 2.67 & 14.0 & 2.70 & 0.18 & 0.050 & 1.63 & 47.0 & 7.8 \\
\hline & & Min & 9.3 & 6.7 & 6.7 & 0.78 & 1.1 & 0.28 & 0.01 & 0.002 & 0.33 & 0 & 0.8 \\
\hline & & Avg & 20.9 & 7.8 & 9.3 & 1.54 & 5.1 & 1.04 & 0.03 & 0.013 & 1.04 & 7.0 & 3.81 \\
\hline \multirow{3}{*}{ Site 3} & \multirow{3}{*}{230} & Max & 33.5 & 8.8 & 11.8 & 2.00 & 12.0 & 1.80 & 0.09 & 0.027 & 1.45 & 20.2 & 11.0 \\
\hline & & Min & 9.6 & 6.7 & 6.4 & 0.71 & 0.7 & 0.22 & 0.01 & 0.002 & 0.42 & 0.3 & 1.7 \\
\hline & & Avg & 20.7 & 7.8 & 8.9 & 1.37 & 4.1 & 0.85 & 0.02 & 0.009 & 0.84 & 4.0 & 5.48 \\
\hline \multirow{3}{*}{ Site 4} & \multirow{3}{*}{230} & Max & 32.9 & 8.5 & 11.6 & 2.13 & 12.0 & 1.60 & 0.03 & 0.025 & 1.48 & 15.6 & 11.0 \\
\hline & & Min & 6.7 & 6.6 & 6.0 & 0.61 & 0.0 & 0.19 & 0.01 & 0.002 & 0.40 & 0.0 & 2.4 \\
\hline & & Avg & 20.7 & 7.7 & 8.6 & 1.27 & 4.0 & 0.80 & 0.01 & 0.007 & 0.82 & 3.3 & 6.02 \\
\hline
\end{tabular}

The second approach is an "abnormal" value detection method, as follows:

(1) Suspected abnormal value judgement. For a target value, not including the first and last ones (e.g., ' $x_{i}^{\prime}$ ' in Equations (1)-(3)), if it is either larger or smaller than its adjacent values, then the target value will be regarded as a suspected abnormal value and flagged.

$$
\begin{gathered}
f_{1}=x_{i}-x_{i-1} \\
f_{2}=x_{i+1}-x_{i} \\
f f=f_{1} \times f_{2}
\end{gathered}
$$


where $x_{i}(I=2,3,4, \ldots n-1)$ represents the time series of buoy measurements, excluding the first and last values. So if $f f<0$, the measurement at the $i$ th time will be regarded as a suspected abnormal value.

(2) Abnormal value confirmation. We calculate the average value $\bar{x}$ of raw data after MMR control, the anomaly $\left|x_{\max }-\bar{x}\right|$ between the maximum value $x_{\max }$ and $\bar{x}$, and the anomaly $\left|x_{\text {min }}-\bar{x}\right|$ between the minimum value $x_{\text {min }}$ and $\bar{x}$. The larger value $|x-\bar{x}|$ between $\left|x_{\max }-\bar{x}\right|$ and $\left|x_{\text {min }}-\bar{x}\right|$ will be chosen to compare with the absolute value $|f f|$ of $f f$. If $|f f|$ is larger than, or equal to, $|x-\bar{x}|^{2}$, then the measurement at the $i^{\text {th }}$ time will be confirmed as an abnormal value.

\subsection{Change Point and Trend Detections}

The Pettitt test was used to automatically detect change points in the data series once a week. Pettitt's test is a nonparametric test to detect a single change point in a time series with continuous data. Its calculation procedures can be found in detail in [24]. The identified change points were then compared to the minimum and maximum values for each sensor. If their values are all in MMR, the validity of change point values will be confirmed. Otherwise the values will be removed from the time series or marked for further check. An exploratory analysis was also carried out to detect the trend of hourly and daily data for all the parameters using the Mann-Kendall method once a week. If the serial data kept increasing or decreasing for more than one week, its validity would be manually and carefully investigated.

\subsection{Data Availability, Daily and Hourly Data Calculation}

Most of the buoy monitoring datasets at the lake area (Buoy_surface, Buoy_profiler, Met_station) commenced in September 2015. The River_station data collection began in August 2016 and the Flux_station and Hydro_station data collection began in April 2017. A software developed by the authors is used to analyse and summarise the high-frequency data, including the calculation of daily and hourly values, based on quality-controlled raw data. Small data gaps without measurements ( $\leq$ days) are interpolated by the software and the large data gaps are arbitrarily set up with a unique flag number (e.g., ' 8888 '), which will be not included for calculating daily and hourly values.

\section{Results}

\subsection{Buoy Photographs}

Figure 2 shows photographs of the Buoy_surface system at site 5 (Figure 2A), located at the mouth of largest tributary (Xinan River, Figure 1), and the Buoy_profiler system at site 4 (Figure 2B), located at the deepest area in front of the dam for the power station (Figure 1), which is the only outflow. The web interface, which dynamically updates all station data from the database, allows the user to make requests for time periods of interest, review data from specific sites, visualise data as a function of time, and perform simple statistical analyses of the real-time data. All historical data from the monitoring system can be downloaded through the web interface by authorised users.
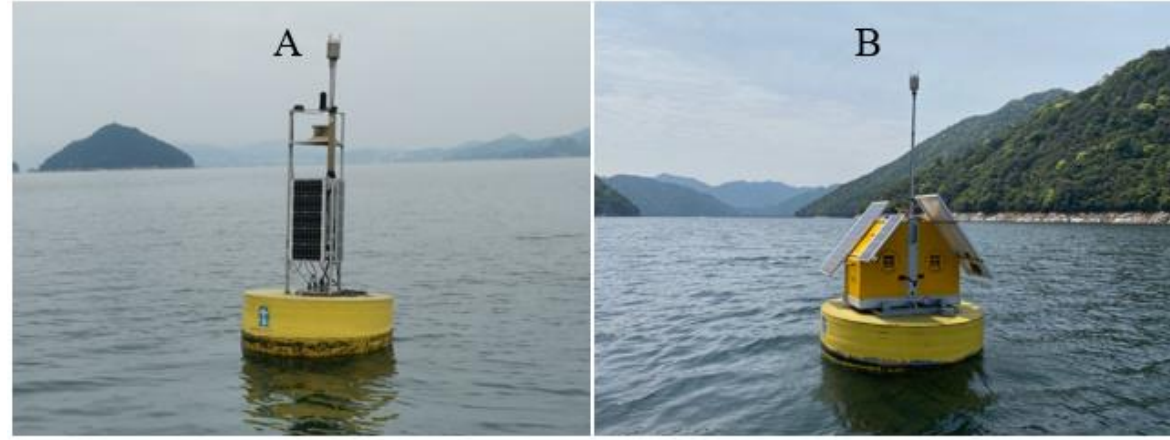

Figure 2. Pictures of (A) the Buoy_surface system at site 5, (B) the Buoy_profiler at site 4. 


\subsection{Surface Measurements}

The measurements from site 5 are presented here as an example, and show the daily and hourly variations in surface WQ measured by the buoy probes. Figure 3A shows the time series of daily surface WT from 30 September 2015 to 1 August 2020, and daily surface DO, CHLA and PC from 27 January 2016 to 1 August 2020. The values of maximum (Max), minimum (min), average and standard deviation (Stdev) for WT, DO, CHLA and PC at site 5 are given in Table 3. All the maximum values for WT, CHLA and PC occurred in summer, but their lowest observations occurred in winter (PC) or spring (WT, DO and CHLA). CHLA and PC showed higher variability over time than those of WT and DO during the study period, based on their statistical Stdevs compared to their average values.
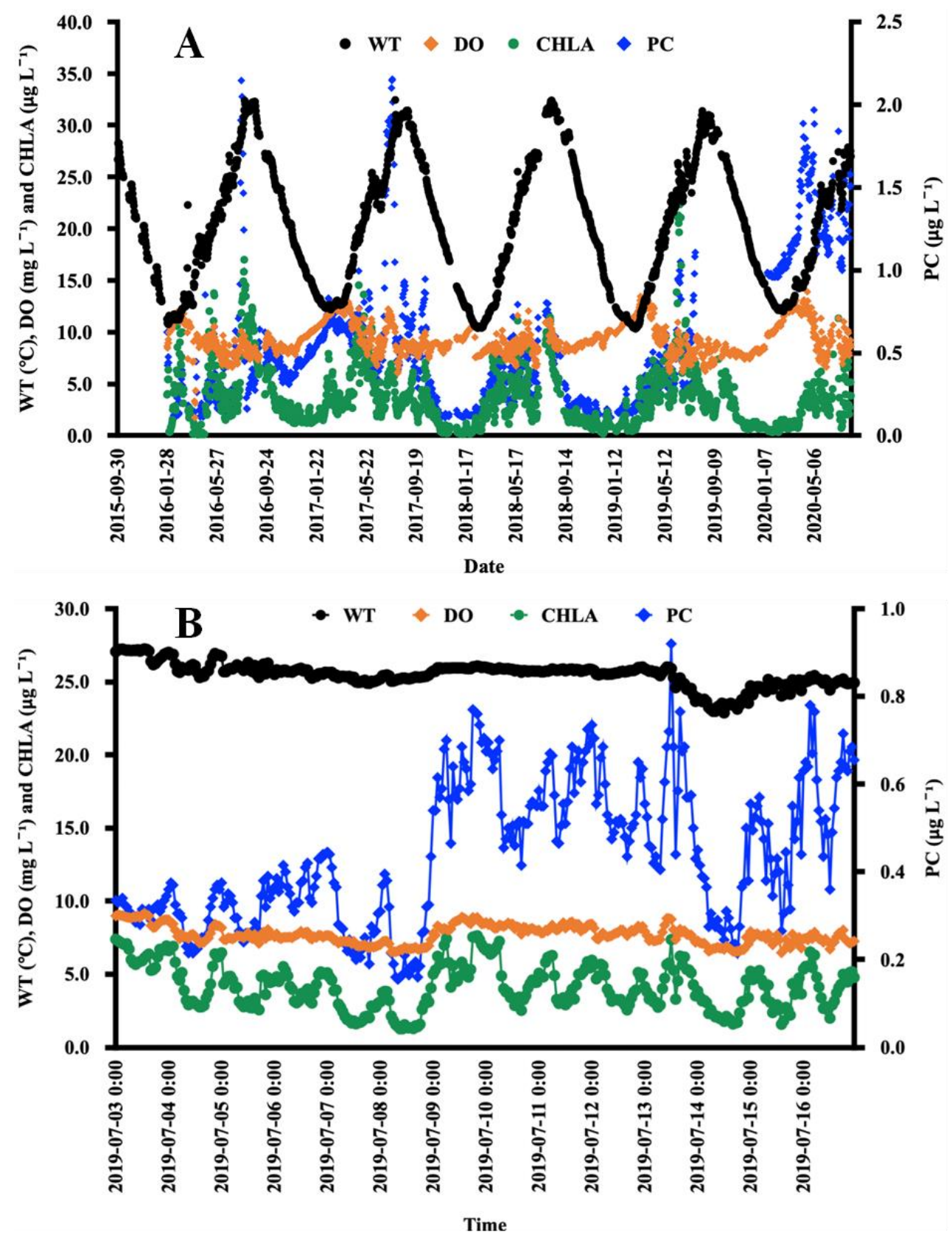

Figure 3. Time serials of (A) daily and (B) hourly WT (black dots, ${ }^{\circ} \mathrm{C}$ ), DO (orange diamonds, $\mathrm{mg} \mathrm{L}^{-1}$ ), CHLA (green dots, $\mu \mathrm{g} \mathrm{L}^{-1}$ ) and PC (blue diamonds, $\mu \mathrm{g} \mathrm{L}^{-1}$ ) at site 5 . Left $\mathrm{Y}$-axes is for WT, DO and CHLA, and right Y-axes is for PC. X-axes is for date in format of year-month-day. 
Table 3. Statistical summaries of surface WT, DO, CHLA and PC measured by monitoring buoys at site 5 and site 6 .

\begin{tabular}{|c|c|c|c|c|c|c|c|c|}
\hline \multirow[t]{2}{*}{ Site } & \multirow[t]{2}{*}{ Parameter } & \multicolumn{2}{|c|}{$\operatorname{Max}$} & \multicolumn{2}{|r|}{ Min } & \multirow[t]{2}{*}{ Avg. } & \multirow[t]{2}{*}{ Stdev } & \multirow[t]{2}{*}{$n$} \\
\hline & & Value & Date & Value & Date & & & \\
\hline \multirow{4}{*}{ Site 5} & $\mathrm{WT}\left({ }^{\circ} \mathrm{C}\right)$ & 32.4 & 30 July 2017 & 10.3 & 1 March 2019 & 20.2 & 6.3 & 1617 \\
\hline & $\mathrm{DO}\left(\mathrm{mg} \mathrm{L}^{-1}\right)$ & 13.9 & 18 April 2020 & 1.7 & 3 April 2016 & 9.3 & 1.6 & 1546 \\
\hline & CHLA $\left(\mu \mathrm{g} \mathrm{L}^{-1}\right)$ & 24.3 & 17 June 2019 & 0.1 & 9 April 2016 & 3.6 & 3.0 & 1530 \\
\hline & $\mathrm{PC}\left(\mu \mathrm{g} \mathrm{L}{ }^{-1}\right)$ & 2.15 & 23 July 2017 & 0.1 & 10 February 2016 & 0.5 & 0.4 & 1318 \\
\hline
\end{tabular}

To show diel variation, hourly data of WT, DO, CHLA and PC at site 5 for the period of 00:00 a.m. 3 July 2019-11:00 p.m. 16 July 2019, without data gaps, are presented as an example in Figure 3B. CHLA and PC show obvious diel variation with higher values in daytime relative to night time, while WT and DO keep more constant than CHLA and PC, showing no diel variation. The Pearson correlation coefficient between WT and DO is 0.8 $(n=336)$, suggesting that surface DO was mainly controlled by WT for the lake.

\subsection{Profiling Measurements}

Profiles of WT, DO, CHLA and PC at site 4 (deepest area) for 1 January 2016-10 July 2020 are shown in Figure 4. The maximum measurement depth was $65 \mathrm{~m}$ at this site. WT (Figure 4A) profiles show a monomictic pattern of mixing with thermal stratification in summer and mixing in winter, although some periods and layers lacked measurements. The TDs were $9.2 \mathrm{~m}, 9.4 \mathrm{~m}, 12.1 \mathrm{~m}$ and $7.8 \mathrm{~m}$ in the summer (July-September) of 2016, 2017 and 2018 and July of 2019 (data not available in August and September). The TD in 2018 were greater than other years, which suggests that the stratification in the summer of 2018 was more intensive than in 2016, 2017 and 2019. Correspondingly, bottom hypoxia events were observed during the stratification of all years. Average bottom DO values (Figure 4B) during stratification were $7.0 \mathrm{mg} \mathrm{L}^{-1}, 7.7 \mathrm{mg} \mathrm{L}^{-1}, 8.2 \mathrm{mg} \mathrm{L}^{-1}$ and $7.7 \mathrm{mg} \mathrm{L}^{-1}$ in 2016, 2017, 2018 and 2019, respectively. The lowest DO values were $1.0 \mathrm{mg} \mathrm{L}^{-1}, 2.0 \mathrm{mg} \mathrm{L}^{-1}$, $1.6 \mathrm{mg} \mathrm{L}^{-1}$ and $2.9 \mathrm{mg} \mathrm{L}^{-1}$, observed on 4 April 2016, 9 December 2017, 1 January 2018 and 13 January 2019, respectively.

CHLA (Figure 4C) followed a similar pattern to WT, with higher values in summer than in winter, suggesting that the biomass of phytoplankton is mainly regulated by water temperature instead of nutrients. The phytoplankton was mostly distributed in the upper $15 \mathrm{~m}$ except for late 2018 and early 2019, when phytoplankton could still be found at a depth of $30 \mathrm{~m}$. PC values (Figure 4D) were much smaller than CHLA at the same depth. It didn't have distinct seasonal variation, but was obviously stratified in the summer of 2018 with a higher concentration in the lower layer than the upper layer.

\subsection{Real-Time Early Warning Information}

The Ministry of Ecology and Environment of China (MEEC) issued state standards for surface water quality in 2002 [25] in order to better manage surface water in China. Lake Qiandao was required to meet Grade I (Table 4, the requirements for heavy metal were not shown in the table) since it provides drinking water for approximately half a million people in Chun'an County (located to the northeast of lake), and a total of 10 million people in both Hangzhou City and Jiaxing City, with water diverted through a tunnel of more than $110 \mathrm{~km}$ in length. DO and $\mathrm{pH}$ are the only two parameters which were measured by wireless sonde, deployed with monitoring buoys at the lake. The statistical analysis results for $\mathrm{DO}$ and $\mathrm{pH}$ are shown in Table 5. There were totally 275 and 130 samples of $\mathrm{pH}$ and DO out of their MMRs at site 5, accounting for $11.0 \%$ and $8.0 \%$ of all the valid samples, respectively. The percentages of $\mathrm{pH}(21.5 \%)$ and $\mathrm{DO}(11.3 \%)$ at site 6 were more than those at site 5. The observed maximum/minimum/average values of $\mathrm{pH}$ at site 5 and site 6 were 9.9/9.002/9.22 and 12.2/9.0002/9.62, respectively. Thus, the maximum $\mathrm{pH}$ at site 6 is much greater than that at site 5 , showing that $\mathrm{pH}$ was more variable at site 6 than at site 5 . 
However, DO followed a reverse pattern, with more varied values at site 5 compared to site 6. Its lowest value was as low as $1.74 \mathrm{mg} \mathrm{L}^{-1}$, observed on 3 April 2016.
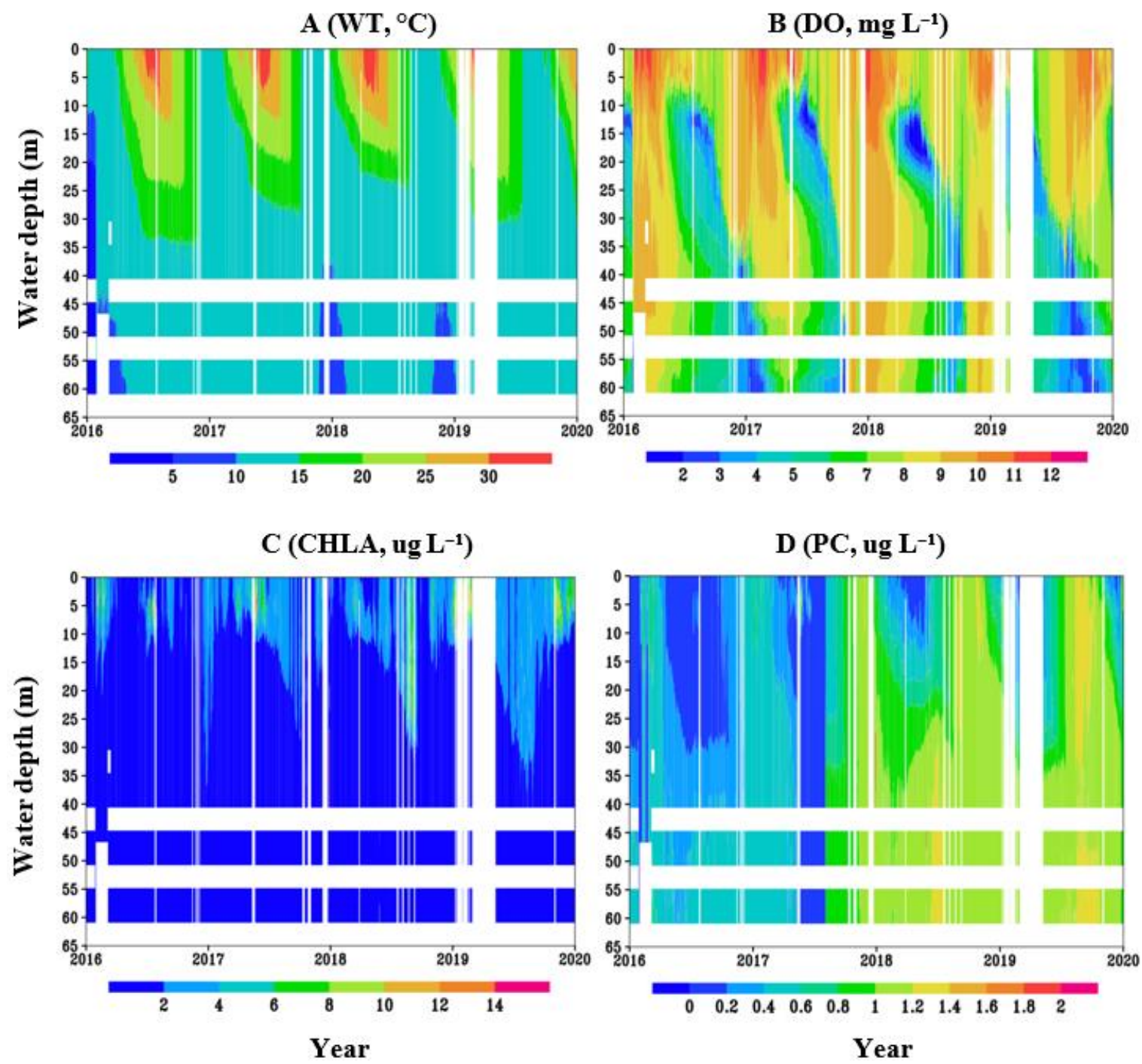

Figure 4. Daily (A)WT, (B) DO, (C) CHLA and (D) PC profiles at site 4 for 1 January 2016-10 July 2020. Y-axes for (A-D) represent water depth $(\mathrm{m})$ and X-axes represent years from 2016 to 2020. White areas denote lack of measurements.

Table 4. Threshold of WQ parameters required for Lake Qiandao.

\begin{tabular}{|c|c|c|c|c|c|c|c|c|}
\hline Parameter & $\mathrm{pH}$ & $\begin{array}{c}\text { DO } \\
\left(\mathrm{mg} \mathrm{L}^{-1}\right)\end{array}$ & $\begin{array}{c}\text { PI } \\
\left(\mathrm{mg} \mathrm{L}^{-1}\right)\end{array}$ & $\underset{\left(\mathrm{mg} \mathrm{L}^{-1}\right)}{\mathrm{COD}}$ & $\begin{array}{c}\text { BOD5 } \\
\left(\mathrm{mg} \mathrm{L}^{-1}\right)\end{array}$ & $\begin{array}{c}\mathrm{NH}_{4}-\mathrm{N} \\
\left(\mathrm{mg} \mathrm{L}^{-1}\right)\end{array}$ & $\begin{array}{c}\text { TP } \\
\left(\mathrm{mg} \mathrm{L}^{-1}\right)\end{array}$ & $\begin{array}{c}\mathrm{TN} \\
\left(\mathrm{mg} \mathrm{L}^{-1}\right)\end{array}$ \\
\hline $\begin{array}{l}\text { Threshold } \\
\text { for Grade I }\end{array}$ & $6-9$ & $\geq 7.5$ & $\leq 2$ & $\leq 15$ & $\leq 3$ & $\leq 0.15$ & $\leq 0.01$ & $\leq 0.2$ \\
\hline
\end{tabular}

Table 5. Statistical analysis results of DO and $\mathrm{pH}$ for early warning at site 5 and site 6 .

\begin{tabular}{ccccc}
\hline Statistical Results & \multicolumn{2}{c}{ Site 5 } & \multicolumn{2}{c}{ Site 6 } \\
\cline { 2 - 5 } & $\mathbf{p H}$ & $\mathbf{D O}$ & $\mathbf{p H}$ & DO \\
\hline Number of all available data & 1573 & 1618 & 1128 & 1128 \\
Number of EWS data & 275 & 130 & 242 & 128 \\
Max & 9.9 & 7.5 & 12.2 & 7.5 \\
Min & 9.002 & 1.74 & 9.0002 & 6.2 \\
Avg. & 9.22 & 6.92 & 9.62 & 6.99 \\
\hline
\end{tabular}




\section{Discussion}

The EWS is now being used for giving real-time early warning signals by judging if the measurements of each sensor are out of the corresponding MMR and meet the required WQ grade. Unfortunately, $\mathrm{DO}$ and $\mathrm{pH}$ are the only two parameters which were directly measured by the buoy sensor and which can be used for the early warning of WQ at this lake. Therefore, it should be considered seriously whether sensors measuring nutrients (e.g., TN, TP, $\mathrm{NH}_{4}-\mathrm{N}, \mathrm{COD}$ and PI) should be added to the buoys, or whether a model (e.g., AEM3D) simulating these nutrients based on high-frequency monitoring data, needs to be developed for providing more satisfactory early warning signals.

The system is also providing data for horizontal interpolation, to produce an initial condition for AEM3D predicting HABs and WQ at a time scale of seven days. For a WQ and $\mathrm{HAB}$ prediction system, initial and boundary conditions are very important to improve prediction accuracy. The initial conditions include horizontal and vertical WQ distribution within the waterbody (e.g., TN, TP and CHLA concentrations at each grid location). A huge challenge with initial conditions derives from the limited number of monitoring buoys collecting high-frequency WQ data, due to economic considerations, which leads to an inaccurate spatial distribution of WQ (e.g., high spatial patchiness of cyanobacterial bloom). However, many advanced interpolation methods are now available to address this issue. Inaccurate spatial WQ distribution in model initialisation can lead to inaccurate WQ prediction at each grid location, and thus unconvincing algal aggregation caused by winds. However, temporal and spatial difficulties prevent conventional methods for water sampling and laboratory analysis to meet the requirements for producing model initial conditions. A comprehensive approach is required, integrating high-frequency buoy monitoring data, laboratory data, satellite images and other available resources to provide a satisfactory spatial WQ concentration for the initialization of predictive simulation systems.

WQ sonde (multi-sensor probes) measurements can efficiently provide data wirelessly at a high temporal resolution, but potential problems could include data distortion due to sensor faults, or data gaps because of failed data storage and/or transfer. Therefore, data QC procedures are necessary before using the sensor measurements. The first step for QC is typically to detect missing series and estimate missing values by relying on neighbouring observations, then to detect unreasonable values out of range between the upper and the lower limits for each parameter, ideally guided by experience for a specific water body and measurement type. Unreasonable values can be removed and substituted with interpolated values. If many successive measurements from the same sensor are of the same exact value, they should usually also be removed and interpolated with neighbouring values, or excluded from data analysis. The final step is to detect outliers (incorrect or out-of-range) measurements, which can be removed or assumed to be missing [26]. Outliers are typically those observations which represent abrupt increases or decreases compared to the neighbouring values. There are many methods [26-28] and pieces of software [29] available for data QC. In this paper, we adopted the outlier detection method for finding anomalous values, which were removed and generally replaced with interpolated values. The detections of change points and trends will further help to find abnormal values or sonde problems. In our system, interpolation was not implemented to reproduce actual missing values due to the high potential for erroneous measurement generation when interpolating over longer time periods. Therefore, interpolation methods or software need to be integrated into this system in order to produce data without measurement.

The whole buoy monitoring system was originally designed to provide essential WQ information, in order to meet Grade I at the required sites. Therefore, Buoy_profilers were deployed at site 1, site 3 and site 4, and Buoy_surface was deployed at site 5. However, the buoys can only monitor WT, DO, pH, CHLA, PC and TURB. It is very difficult and expensive to directly and accurately measure $\mathrm{TN}, \mathrm{TP}, \mathrm{NH}_{4}-\mathrm{N}, \mathrm{PI}, \mathrm{COD}$ and $\mathrm{BOD}_{5}$ at a high frequency and in near-real-time [30]. An optional solution in this early warning system, is to calculate these parameters based on their regressed relations with sonde-measured values. The calculated values from regressive equations can then provide vital WQ information 
at different zones of the lake, feeding the AEM3D (http:/ / www.hydronumerics.com.au, accessed on 15 January 2022) model for WQ prediction.

The collected data may assist water environmental managers in identifying and predicting the impacts of climatic extreme events [31]. For example, at Lake Qiandao, rainstorms with high rainfall typically result in a large inflow of water and nutrient loading, including N, P, and organic/inorganic matters, leading to an abrupt increase in water level and a significant increase of regional $\mathrm{N}$ and $\mathrm{P}$ concentrations [22]. This remarkably alters the spectral absorption properties of chromophoric dissolved organic matter (CDOM) and particles at the northwestern, southwestern and northeastern areas [32]. HFMS can also provide a useful basis for theory and model developments, improving our understanding of lake (reservoir) responses to perturbations caused by human activities and climate change at different time scales (e.g., sub-hourly, hourly, daily, monthly, seasonally, annually and every decade).

Although HFMS has a wide range of applications, it is now still hampered by several factors. For example, we have a limited choice of water quality sensors that are robust, economic and low-maintenance. The accuracy of the sondes measuring chemical parameters (i.e., phosphorus, ammonium, ammonia and nitrite) and biological parameters (i.e., bacterial enumeration, cyanobacteria, biota and cyanotoxins) still needs to improve, although the fast spread of HFMS is encouraging sensor developers to improve technology as quickly as they can. For giving better early warning signals and real-time WQ assessment, in the future, it will be necessary to add sondes measuring chemical and biological parameters to the current HFMS.

Author Contributions: Conceptualization, L.L. and H.L.; methodology, L.L.; software, L.L.; validation, J.L. (Jia Lan), Y.W., Z.W. and C.M.; formal analysis, (J.L.) Jialong Li; investigation, Y.W.; resources, Y.W.; data curation, F.L., L.C. and G.W.; writing — original draft preparation, L.L.; writing-review and editing, C.M. and H.Z.; visualization, L.L., R.Z. and F.G.; supervision, L.L.; project administration, L.L. and H.L.; funding acquisition, L.L. All authors have read and agreed to the published version of the manuscript.

Funding: This research was funded by Yunnan University (C176220100043), Yunnan Provincial Department of Science and Technology (202001BB050078), National Natural Science Foundation of China (41671205, 42171034), and the Yunnan Provincial Government Leading Scientist Program (2015HA024).

Institutional Review Board Statement: Not applicable.

Informed Consent Statement: Not applicable.

Acknowledgments: The project was supported by Yunnan University (C176220100043), Yunnan Provincial Department of Science and Technology (202001BB050078), National Natural Science Foundation of China (41671205, 42171034), and the Yunnan Provincial Government Leading Scientist Program (2015HA024).

Conflicts of Interest: The authors declare no conflict of interest.

\section{References}

1. Greeson, P.E. Lake eutrophication-A natural process. J. Am. Water Resour. Assoc. 1969, 5, 16-30. [CrossRef]

2. Anderson, D.M.; Glibert, P.M.; Burkholder, J.M. Harmful algal blooms and eutrophication: Nutrient sources, composition, and consequences. Estuaries 2002, 25, 704-726. [CrossRef]

3. Smith, V.H.; Schindler, D.W. Eutrophication science: Where do we go from here? Trends Ecol. Evol. 2009, 24, 201-207. [CrossRef]

4. Conley, D.J.; Paerl, H.W.; Howarth, R.W.; Boesch, D.F.; Seitzinger, S.P.; Havens, K.E.; Lancelot, C.; Likens, G.E. Controlling eutrophication: Nitrogen and phosphorus. Sciences 2009, 323, 1014-1015. [CrossRef]

5. Lee, J.H.W.; Hodgkiss, I.J; Wong, K.T.M.; Lam, I.H.Y. Real time observations of coastal algal blooms by an early warning system. Estuar. Coast. Shelf Sci. 2005, 65, 172-190. [CrossRef]

6. Wang, X.; Su, J.; Cai, Y.; Tan, Y.; Yang, Z.; Wang, F. An integrated approach for early warning of water stress in shallow lakes: A case study in Lake Baiyangdian, North China. Lake Reserv. Manag. 2013, 29, 285-302. [CrossRef]

7. Burchard-Levine, A.; Liu, S.; Vince, F.; Li, M.; Ostfeld, A. A hybrid evolutionary data driven model for river water quality early warning. J. Environ. Manag. 2014, 143, 8-16. [CrossRef] 
8. Park, Y.; Cho, K.H.; Park, J.; Cha, S.M.; Kim, J.H. Development of early-warning protocol for predicting chlorophyll-a concentration using machine warning models in freshwater and estuarine reservoirs, Korea. Sci. Total Environ. 2015, 502, 31-41. [CrossRef]

9. Biddanda, B.A.; Weinke, A.D.; Kendall, S.T.; Gereaux, L.C.; Holcomb, T.M.; Snider, M.J.; Dila, D.K.; Long, S.A.; VandenBerg, C.; Knapp, K.; et al. Chronicles of hypoxia: Time-series buoy observations reveal annually recurring seasonal basin-wide hypoxia in Muskegon Lake-A Great Lakes estuary. J. Great Lakes Res. 2018, 44, 219-229. [CrossRef]

10. Delpla, I.; Florea, M.; Rodriguez, M.J. Drinking water source monitoring using early warning systems based on data mining techniques. Water Resour. Manag. 2019, 33, 129-140. [CrossRef]

11. Glasgow, H.B.; Burkholder, J.M.; Reed, R.E.; Lewitus, A.J.; Kleinman, J.E. Real-time remote monitoring of water quality: A review of current applications, and advancements in sensor, telemetry, and computing technologies. J. Exp. Mar. Biol. Ecol. 2004, 300, 409-448. [CrossRef]

12. Ungureanu, F.; Lupu, R.G.; Stan, A.; Craciun, I.; Teodosiu, C. Towards real time monitoring of water quality in river basins. Environ. Eng. Manag. J. 2010, 9, 1267-1274. [CrossRef]

13. Storey, M.V.; van der Gaag, B.; Burns, B.P. Advances in on-ling drinking water quality monitoring and early warning systems. Water Res. 2011, 45, 741-747. [CrossRef]

14. Qi, X.; Wang, S.; Jiang, Y.; Liu, P.; Li, Q.; Hao, W.; Han, J.; Zhou, Y.; Huang, X.; Liang, P. Artificial electrochemically active biofilm for improved sensing performance and quickly devising of water quality early warning biosensors. Water Res. 2021, $198,117164$. [CrossRef]

15. Zhang, C.; Pei, H.; Jia, Y.; Bi, Y.; Lei, G. Effects of air quality and vegetation on algal bloom early warning systems in large lakes in the middle-lower yangtze river basin. Environ. Pollut. 2021, 285, 117455. [CrossRef] [PubMed]

16. Kumar, T.; Naik, S.; Jujjavarappu, S.E. A critical review on early-warning electrochemical system on microbial fuel cell-based biosensor for on-site water quality monitoring. Chmesphere 2022, 291, 133098. [CrossRef] [PubMed]

17. Ungureanu, F.; Balasa, M.I. Sensor networks in waste water treatment monitoring. Environ. Manag. J. 2007, 6, 65-70. [CrossRef]

18. Tang, M.; Si, W.; Zhong, S. Development of automatic water quality monitoring network at Lake Taihu, Jiangsu Province. Environ. Dev. 2017, 2, 91-95. (In Chinese)

19. $\mathrm{Wu}, \mathrm{J} . ;$ Kong, L.; Yang, J.; Li, Y. Design and development of the integrated platform for environmental monitoring and information management for Lake Dianchi. Technol. Innov. Appl. 2018, 15, 79-80. (In Chinese)

20. Zhang, Y.; Wu, Z.; Liu, M.; He, J.; Shi, K.; Wang, M.; Yu, Z. Thermal structure and response to long-term climatic changes in Lake Qiandaohu, a deep subtropical reservoir in China. Limnol. Oceanogr. 2014, 59, 1193-1202. [CrossRef]

21. Durre, I.; Menne, M.J.; Vose, R. Strategies for evaluating quality assurance procedures. J. Appl. Meteorol. Climatol. 2008, 47, 1785-1791. [CrossRef]

22. Zhang, Y.; Lan, J.; Li, H.; Liu, F.; Luo, L.; Wu, Z.; Yu, Z.; Liu, M. Estimation of external nutrient loadings from the main tributary (Xin'anjiang) into Lake Qiandao, 2006-2016. J. Lake Sci. 2019, 31, 1534-1546. (In Chinese)

23. Xiang, C.; Yan, L.; Han, Y.; Wu, Z.; Yang, W. Valuation of ecosystem services of the Thousand-Island Lake, Zhejiang, China. Chin. J. Appl. Ecol. 2019, 30, 3875-3884. (In Chinese)

24. Pettitt, A.N. A nonparametric approach to the change-point problem. J. R. Stat. Society. Ser. C 1979, $28,126-135$.

25. Ministry of Ecology and Environment of China (MEEC). State Standards for Surface Water Quality (GB 3838-2002); China Environmental Press: Beijing, China, 2002.

26. Gonzalez-Rouco, J.F.; Jimenez, J.L.; Quesada, V.; Valero, F. Quality control and homogeneity of precipitation data in the southwest of Europe. J. Clim. 2001, 14, 964-978. [CrossRef]

27. Li, X.; Li, F. Quality control of online oceanic and meteorological data. Mar. Forecast. 1997, 14, 71-78. (In Chinese)

28. Gokturk, O.M.; Bozkurt, D.; Sen, O.L.; Karaca, M. Quality control and homogeneity of Turkish precipitation data. Hydrol. Processes 2008, 22, 3210-3218. [CrossRef]

29. Araya-Lopez, J.L.; Kalyuzhnaya, A.V.; Kosukhin, S.S.; Ivanov, S.V. Data quality control for St. Petersburg flood warning system Procedia Comput. Sci. 2016, 80, 2128-2140. [CrossRef]

30. Banna, M.H.; Imran, S.; Francisque, A.; Najjaran, H.; Sadiq, R.; Rodriguez, M.; Hoorfar, M. Online drinking water quality monitoring: Review on available and emerging technologies. Crit. Rev. Environ. Sci. Technol. 2014, 44, 1370-1421. [CrossRef]

31. Marcé, R.; George, G.; Buscarinu, P.; Deidda, M.; Dunalska, J.; de Eyto, E.; Flaim, G.; Grossart, H.-P.; Istvanovics, V.; Jennings, E.; et al. Automatic High Frequency Monitoring for Improved Lake and Reservoir Management. Environ. Sci. Technol. 2016, 50, 10780-10794. [CrossRef]

32. Shi, L.; Mao, Z.; Liu, M.; Zhang, Y. Effects of rainstorm on the spectral absorption properties of chromophoric dissolved organic matter and particles in Lake Qiandao. J. Lake Sci. 2018, 30, 358-374. (In Chinese) 